\title{
PENGEMBANGAN SOSIAL- EMOSIONAL ANAK MELALUI METODE ROLE PLAYING (BERMAIN PERAN) DI KELOMPOK B ANAK USIA DINI
}

\author{
Sri Jamilah, $M A .^{1}$ \\ INSTITUT AGAMA ISLAM MUHAMMADIYAH BIMA \\ Email:ssitasita321@gmail.com
}

\begin{abstract}
:
This article is titled Child social-emotional development through the Role Playing method in Group B Early Childhood. The aim is to know the child's social-emotional development through the Role Playing method in Group B of Early Childhood.

Child social-emotional development through the Role Playing method (role playing) in Group B Early Childhood is the development of imagination and appreciation of children who act as subjects of active learning. Role playing activities discussed in this study are one of the efforts to improve children's social emotional abilities by developing imagination and appreciation by students by acting as living figures or inanimate objects. This game is generally carried out by more than one person, it depends on what is played.
\end{abstract}

Keywords: Social \& Emosiaonal Development, and Role Method Playing (role playing)

\section{A. PENDAHULUAN.}

Anak dilahirkan dengan potensi mampu berkembang secara baik, tetapi mereka tidak mungkin sepenuhnya melakukan secara sendiri. Anak-anak dalam pengembangan dirinya, termasuk pada aspek sosial emosional membutuhkan bantuan dan program yang sesuai dengan kebutuhannya. Tindakan-tindakan untuk mencerdaskan dimensi perkembangannya itu perlu ditangani secara serius. Artikel ini mengangkat pentingnya menangani kecerdasan sosial emosional anak yang di-

${ }^{1}$ Sri Jamilah, MA. Adalah staff pengajar pada Prodi PIAUD Instutut Agama Islam Muhammadiyah Bima 
lakukan melalui pematangan dan upaya pembelajaran yang tepat. Maka diharapkan anak sebagai generasi yang cerdas sesuai harapan bangsa, orang tua, masyarakat dan agama.

Semua orang tua, guru atau praktisi pendidikan mengharapkan anak didiknya mampu menguasai atau mengendalikan emosi dan menguasai keterampilan sosial dalam kehidupannya, baik di dalam lingkungan sosial (masyarakat) maupun lingkungan pendidikan anak diharapkan mampu beradaptasi atau menyesuaikan diri sedini mungkin seperti pada lingkungan Kelompok Bermain (KB), Pendidikan Anak Usia Dini (PAUD) dan Taman Kanak-kanak (TK).

Pendidikan di Taman Kanak-kanak (TK), Pendidikan Anak Usia Dini (PAUD), memberikan kebebabasan dan spontanitas yang cukup pada anak dalam memilih berbagai aktivitas, mereka diijinkan untuk beralih dari satu aktifitas ke aktivitas lainnya sesuai keinginan mereka. Guru lebih bertindak sebagai seorang fasilisator dari pada sebagai seorang pemimpin.

Demikian juga dengan pendidikan anak tentang metode pengembangan sosial emosi anak usia dini, orang tua, guru, dan lingkungan masyarakat yang memberikan kebebasan pada anak untuk beraktivitas dengan dunia sekitarnya. Pengembangan Sosial-Emosiaonal merupakan suatu keadaan/situasi yang utuh dapat berupa pikiran ataupun perasaan yang nampak pada perubahan biologis yang muncul dari prilaku seseorang. Bahasa emosi mengarah pada sebuah perasaan atau pikiran.

Perkembangan Sosial emosional pada anak penting dikembangkan. Karena pertama semakin banyaknya permasalahan yang terjadi di sekitar anak, misalnya lingkungan yang tidak baik ataupun perkembangan teknologi yang semakin canggih seperti televise yang akan membawa dampak luar biasa pada anak karena tontonan yang tidak layak akan mempengaruhi perkembang emosi anak. salah satu bentuk pembelajaran, dimana peserta didik ikut terlibat aktif memainkan peran-peran tertentu. Bermain pada anak merupakan salah satu sarana untuk belajar. Melalui kegiatan bermain yang menyenangkan, anak berusaha untuk menyelidiki dan mendapatkan pengalaman yang kaya, baik pengalaman dengan dirinya sendiri, orang lain maupun dengan lingkungan di sekitarnya.

Jurnal Pelang̉i Jurnal pemikiran dan penelitian pendidkan Islam anak Usia Dini 
Model Pembelajaran merupakan suatu pendekatan pembelajaran yang digunakan untuk meningkatkan sikap, dan pengetahuan siswa. Hal tersebut sejalan dengan pendapat Hanafian, mengatakan bahwa model pembelajaran merupakan salah satu pendekatan dalam rangka mensiasati perubahan perilaku peserta didik secara adaptif maupun generatif. ${ }^{2}$ Salah satu metode yang dipergunakan adalah Role Playing. Role Playing ini adalah merupakan berakting sesuai dengan peran yang telah ditentukan terlebih dahulu. Menurut Sudjana, metode Role Playing adalah suatu cara mengajar dengan jalan mendramatiskan bentuk tingkah laku dalam hubungan sosial. ${ }^{3}$.

Metode Role laying di Taman Kanak-Kanak bahwa guru menerapkan langkah-langkah metode bermain peran (Role Playing) sesuai dengan teori yang mereka pahamai yaitu dimulai dengan guru memilih sebuah tema yang akan dimainkan, guru membuat naskah jalan cerita yang akan diperankan, guru mengumpulkan anak untuk diberikan pengarahan atauran dalam bermain peran (Role Playing). Guru sudah mempersiapkan alat yang akan digunakan saat bermain peran, guru menjelaskan alat-alat yang akan digunakan oleh peserta didik unuk bermain, guru membagikan tugas kepada peserta didk sesuai dengan peran yang akan tugas kepada peserta didik sesuai dengan peran yang akan dimainkan, agar tidak berebut saat berman peran. Guru hanya mengawasi/mendampingi anak dalam bermain, apabila dibutuhkan anak, guru dapat membantu. Guru mengadakan diskusi untuk mengulas kembali nilai-nilai dan pesan yang terkandung dalambermain peran (Role Playing) untuk diteladani peserta didik. ${ }^{4}$

Jadi Pengembangan sosial-Emmosional anak melalui metode Role Playing di Kelompok B Anak Usia dini itu sangan penting. Metode Role Playing sesuai dengan teori yang mereka pahamai yaitu dimulai dengan guru memilih sebuah tema yang akan dimainkan, guru membuat naskah

${ }^{2}$ Dwi Novita Sari. Penerapan Model Pembelajaran Role Playing Untuk Meningkatkan Motivasi dan Hasil Belajar Siswa Pada Mata Pelajaran PKn Kelas IV SD Negeri 2 Kesumadadi, Jurusan Ilmu Pendidikan, Fakultas Keguruan dan Ilmu Pendidikan Universitas Lampung, 2016, hal 17, Dikutip Dari: Hanafiah, 2009: 41

${ }^{3}$ Ibid, hal. 19, Dikutip dari: Sudjana, 2009: 89

${ }^{4}$ Deska Santi Julyasari. Penerapan metode Bermain Peran Dalam Mengembangkan Kreativitas Anak Usia Dini Di Taman Kanak-Kanak Dzakiyah Kedamaian Antasari Bandar lampung. Fakultas Tarbiyah dan Keguruan, Universitas Islam Negeri Raden Intan, Lampung, 2017, hal. iii 
jalan cerita yang akan diperankan, guru mengumpulkan anak untuk diberikan pengarahan atauran dalam bermain peran (Role Playing). Guru sudah mempersiapkan alat yang akan digunakan saat bermain peran, guru menjelaskan alat-alat yang akan digunakan oleh peserta didik unuk bermain, guru membagikan tugas kepada peserta didk sesuai dengan peran yang akan tugas kepada peserta didik sesuai dengan peran yang akan dimainkan, agar tidak berebut saat berman peran. Guru hanya mengawasi/mendampingi anak dalam bermain, apabila dibutuhkan anak, guru dapat membantu

\section{B. PEMBAHASAN}

\section{Pengembangan Sosial-Emosional}

a). Pengertian Perkembangan sosial dan emosi anak usia dini

Sebelum kita membahas tentang perkembangan sosial, emosi dan spiritual Anak Usia Dini terlebih dahulu kita bahas tentang pengertian perkembangan sehingga dalam pembahasan selanjutnya lebih terarah. Perkembangan menurut Santrock adalah pola perubahan yang dimulai sejak pembuahan dan terus berlanjut di sepanjang rentang kehidupan individu sebagian besar perkembangan melibatkan pertumbuhan, namun juga melibatkan kemunduran atau penuaan. Senada denga Santrock, Hurlock mengemukakan bahwa perkembangan merupakan serangkaian perubahan progresif yang terjadi sebagai akibat dari proses kematangan dan pengalaman/ belajar. $^{5}$

Pengertian perkembangan di atas memberikan pemahaman bahwa untuk membahas perkembangan sosial, emosi, dan spiritual anak usia dini berikut tidak lain berasal dari perkembangan anak melalui proses kematangan, dan pengalaman/belajar. Pengertian perkembangan sosial menurut Plato secara potensial (fitrah) manusia dilahirkan sebagai makhluk sosial (zoon politikon), sedangkan menurut Syamsuddin mengungkapkan bahwa sosialisasi adalah proses belajar untuk menjadi makhluk sosial, dan menurut Loree, Sosialisasi merupakan suatu proses dimana individu (terutama) anak melatih kepekaan dirinya terhadap

\footnotetext{
${ }^{5}$ Christiana Hari soetjiningsih, perkembangan Anak sejak pembuahan sampai dengan Kanak-kanak akhir, Prenda,(Jakarta,2014), hal. 2.
}

Jurnal Pelang̉i Jurnal pemikiran dan penelitian pendidkan Islam anak Usia Dini 
rangsangan-rangsangan sosial terutama tekanan-tekanan dan tuntutan kehidupan (kelompoknya) serta belajar bergaul dengan bertingkah laku, seperti orang lain di dalam lingkungan sosialnya.

Muhibin Syah mengatakan bahwa perkembangan sosial merupakan proses pembentukan social self (pribadi dalam masyarakat), yakni pribadi dalam keluarga, budaya, bangsa, dan seterusnya. Adapun Hurlock mengutarakan bahwa perkembangan sosial merupakan perolehan kemampuan berperilaku yang sesuai dengan tuntutan sosial. Sosialisasi adalah kemampuan bertingkah laku sesuai dengan norma, nilai atau harapan sosial. ${ }^{6}$

Berikut ini Pengertian perkembangan sosial, emosi. Emosi adalah perasaan yang ada dalam diri kita, dapat berupa perasaan senang atau tidak senang, perasaan baik atau buruk. Dalam World Book Dictionary sebagaimana dikutip oleh Ali Nugraha dalam bukunya "Metode Pengembangan Sosial Emosional" emosi didefinisikan sebagai berbagai perasaan kuat, Perasaan benci, marah, cinta, senang, dan kesedihan.

Jadi Perkembangan Sosial Emosional menurut Nenide dalam bukunya Cristiana Hari Soetjiningsih, Perkembangan anak sejak pembuahan sampai dengan kanak-kanak akhir adalah mencakup adanya sense of confidence and competence, kemampuan membina hubungan yang baik dengan teman sebaya dan orang-orang dewasa, kemampuan untuk tetap pada tugas, mamiliki arah/tujuan, kemampuan untuk mengidentifikasi memahami dan mengkomunikasikan perasaan/emosinya, kemampuan mengelola emosi yang kuat secara konstruktif. ${ }^{7}$

Anak usia dini adalah anak yang sedang membutuhkan upaya-upaya pendidikan untuk mencapai optimalisasi semua aspek perkembangan baik perkembangaan fisik maupun psikis, yaitu intelektual, bahasa, motorik, dan sosio emosional. ${ }^{8}$ Metode adalah cara menyampaikan ilmu yang tepat sesuai dengan karakteristik anak sehingga menghasilkan pemahaman yang maksimal bagi peserta didik. ${ }^{9}$ Menurut W.J.S Purwadarminta dalam Kamus Umum Bahasa Indonesia bahwasannya metode

${ }^{6}$ Ali Nugraha, Yeni Rahmawati; Metode Pengembangan Sosial Emosional, Universitas Terbuka, (Jakarta, 2009) hal.18.

${ }^{7} \mathrm{Ibid} ; 146$.

${ }^{8}$ Ihlas hasan, Pendidikan Anak Usia Dini, (Konsep,filosofi, dan paradigma baru).(Edukasi Mitra Grafika, Palu,2017), hal.11.

${ }^{9}$ Opik Rofiah Z, Metode Pengembangan Kognitif, (Jakarta: UT; 2005), hal.73. 
merupakan cara yang telah teratur dan terpikir baik-baik untuk mencapai suatu maksud. ${ }^{10}$

Metode Pengembangan sosial dan emosi anak usia dini adalah merupakan cara mengembangkan kemampuan dan membina hubungan sosial dan emosi pada anak, baik anak usia dini maupun dengan orang dewasa, kemampuan anak untuk tetap pada tugas, mengkomunikasikan emosinya serta kemampuan mengelola emosi secara konstruktif.

Dari definisi di atas dapat disimpulkan bahwa perkembangan sosial dan emosi merupakan suatu proses pemerolehan kemampuan untuk berperilaku yang sesuai dengan keinginan yang berasal dari dalam diri seseorang dan sesuai dengan tuntutan dan harapan-harapan sosial yang berlaku di masyarakat.

\section{Metode Pengembangan Sosial dan Emosional Anak Usia Dini}

Untuk menjadi individu yang mampu bermasyarakat diperlukan tiga proses sosialisasi. Proses sosialisasi ini tampaknya terpisah, tetapi sebenarnya saling berhubungan satu sama lainnya, sebagaimana yang dikemukakan oleh Hurlock dalam bukunya Ali Nugraha, metode pengembangan sosial dan emosional, membagi proses perkembangan sebagai berikut:

1. Belajar untuk bertingkah laku dengan cara yang dapat diterima masyarakat.

2. Belajar memainkan peran sosial yang ada di masyarakat.

3. Mengembangkan sikap/tingkah laku sosial terhadap individu lain dan aktivitas sosial yang ada di masyarakat. ${ }^{11}$

Pada perkembangannya ketiga tahap proses sosial ini, individu akan terbagi ke dalam dua kelompok, yaitu kelompok individu sosial dan individu non sosial. Kelompok individu sosial adalah mereka yang tingkah lakunya mencerminkan ketiga proses sosialisasi. Mereka mampu membedakan hal-hal yang dianggap biasa. Adakalanya mereka selalu menginginkan adanya orang lain dan merasa kesepian apabila berada seorang diri. Selain itu mereka juga merasa puas dan bahagia jika selalu berada dengan orang lain. Adapun kelompok individu non sosial,

\footnotetext{
${ }^{10}$ W.J.S. Purwadarminta, Kamus Besar Bahasa Indonesia, (Jakarta: Balai Pustaka, 2005), hal.767.

${ }^{11}$ Ibid ; 18
}

Jurnal Pelangi Jurnal pemikiran dan penelitian pendidkan Islam anak Usia Dini 
mereka adalah orang-orang yang tidak berhasil mencerminkan ketiga proses sosialisasi. Mereka adalah individu yang tidak tahu apa yang diharapkan kelompok sosial sehingga tingkah laku tidak sesuai dengan harapan sosial. Kadang-kadang mereka tumbuh menjadi individu anti sosial, yaitu individu yang mengetahui harapan kelompok sosial, tetapi dengan sengaja melawan hal tersebut. Akibatnya individu anti sosial ini ditolak atau dikucilkan oleh kelompok sosial.

Selain kedua kelompok tadi, dalam perkembangan sosial ini adapula istilah individu yang introvert dan extrovert. Introvert adalah kecendrungan seseorang untuk menarik diri dari lingkungan sosialnya. Minat sikap ataupun keputusan-keputusan yang diambil selalu didasarkan pada perasaan, pemikiran, dan pengalamannya sendiri. Orang-orang dengan kecendrungan introvert, biasanya pendiam dan tidak membutuhkan orang lain karena merasa segala kebutuhannya bisa dipenuhi sendiri. Sedangkan extrovert adalah kecendrungan seseorang untuk mengarahkan perhatian ke luar dirinya sehingga segala minat, sikap, dan keputusan-keputusan yang diambilnya lebih ditentukan oleh peristiwaperistiwa yang terjadi di luar dirinya. Orang-orang extrovert biasanya cenderung aktif, suka berteman, dan ramah tamah. ${ }^{12}$

Introvert dan extrovert hanya merupakan suatu tipe dari reaksi yang ditunjukkan seseorang. Jika seseorang menunjukkan reaksi yang terusmenerus seperti itu atau sudah menjadi kebiasaan barulah bisa dianggap sebagai tipe kepribadiannya. Sementara kepribadian yang sehat atau seimbang haruslah memiliki kedua kecendrungan ini. Dengan demikian, kebutuhan untuk berhubungan dengan lingkungan sosialnya serta kebutuhan akan prestasi dan refleksi diri keduanya bisa terpuaskan.

Demikian juga dalam aktivitas bermainpun bagi seorang anak memiliki peranan yang cukup besar dalam mengembangkan kecakapan sosialnya sebelum anak mulai berteman. Aktivitaas bermain menyiapkan anak dalam menghadapi pengalaman sosialnya. Sebagaimana yang dipaparkan oleh Ali Nugraha dalam bukunya Metode Pengembangan Sosial Emosional memaparkan sikap yang dapat dikembangkan melalui kegiatan bermain sebagai berikut:

1. Sikap sosial, Bermain mendorong anak untuk meninggalkan pola

${ }^{12}$ Ibid ; 19 
berfikir egosentrisnya. Dalam situasi bermain anak "dipaksa" untuk mempertimbangkan sudut pandang teman bermainnya sehingga anak kurang menjadi egosentris. Dalam permainan, anak belajar bekerja sama untuk mencapai tujuan bersama. Mereka mempunyai kesempatan untuk belajar menunda kepuasan sendiri selama beberapa menit, misalnya saat menunggu giliran bermain. Anakpun terdorong untuk belajar berbagi, bersaing dengan jujur, menang atau kalah dengan sportif, mempertahankan haknya, dan peduli terhadap hak-hak orang lain. Lebih lanjut anakpun akan belajar makna kerja tim dan semangat tim.

2. Belajar Berkomunikasi, untuk dapat bermain dengan baik bersama orang lain, anak harus bisa mengerti dan dimengerti oleh temantemannya. Hal ini dapat mendorong anak untuk belajar bagaimana berkomunikasi dengan baik, bagaimana membentuk hubungan sosial, bagaimana menghadapi dan memecahkan masalah-masalah yang timbul dalam hubungan tersebut.

3. Belajar Mengorganisasi, saat bermain bersama orang lain, anak juga berkesempatan belajar 'berorganisasi'. Bagaimana ia harus melakukan pembagian peran diantara mereka yang turut serta dalam permainan tersebut, misalnya siapa yang menjadi guru dan siapa yang menjadi muridnya.

4. Lebih menghargai orang lain dan perbedaan-perbedaan, bermain memungkinkan anak mengembangkan kemampuan empatinya. Saat bermain dalam sebuah peran, misalnya anak tidak hanya memerankan identitaas si tokoh, tetapi juga pikiran-pikiran dan perasaanperasaan tokoh tersebut. Permainan (bermain Peran) membantu anak membangun pemahaman yang lebih baik atas orang lain. Lebih toleran, serta mampu berlapang dada terhadap perbedaan-perbedaan yang dijumpai.

Menghargai Harmoni dan Kompromi, Saat dunianya semakin luas dan kesempatan berinteraksi semakin sering dan bervariasi maka akan tumbuh kesadarannya akan makna peran sosial, persahabatan, perlunya menjalin hubungan serta perlunya strategi dan diplomasi dalam berhubungan dengan orang lain. Anak tidak akan begitu saja merebut permainan teman, misalnya ia tahu akan konsekuensi ditinggalkan atau 
dimusuhi. ${ }^{13}$

Dari lima hal tersebut di atas dapat dikatakan bahwa proses perkembangan sosial anak dapat ditingkatkan dengan beberapa hal termasuk dalam hal bermain. Selain itu Bambang Sujiono dalam bukunya Mencerdaskan Perilaku AnakUsia Dini, menjelaskan bahwa ada beberapa proses penanaman nilai sosial anak dimana dalam perkembangan sosial setiap anak akan melalui sebuah proses panjang yang pada akhirnya nilai-nilai sosial tersebut menjadi bagian dalam diri seorang anak berikut adalah alur proses sosialisasi pada setiap individu mulai sejak lahir sampai ia menjadi dewasa proses tersebut sebagai berikut:

1. Proses Imitasi

Berupa proses peniruan terhadap tingkah laku atau sikap serta cara pandang orang dewasa (model) dalam aktivitas yang dilihat anak yang secara sengaja belajar bergaul dari orang-orang terdekatnya (orang tua). Untuk itu selain membimbing dan mengajarkan anak bagaimana bergaul dengan tepat, orang tua juga dituntut untuk menjadi model yang baik bagi anaknya.

2. Proses Identifikasi

Berupa proses terjadinya pengaruh sosial pada seseorang yang didasarkan pada orang tersebut untuk menjadi seperti individu lain yang dikaguminya. Atau dengan perkataan lain proses menyamakan tingkah laku sosial orang yang berada disekitarnya sesuai dengan perannya kelak di masyarakat. Untuk itu selain memberi kepercayaan dan kesempatan, orang tua (orang dewasa) juga diharapkan dapat memberikan penguatan lewat pemberian ganjaran atau hadiah apabila tingkah laku anak positif atau hukuman apabila ia melakukan kesalahan. Proses ini berlangsung terus sampai masa prapubertas.

3. Proses Internalisasi

Proses penanaman serta penyerapan nilai-nilai, atau dengan perkataan lain, relatif mantap dan menetapnya suatu nilai-nilai sosial pada diri seseorang. Sehingga nilai-nilai tersebut tertanam dan menjadi milik orang tersebut. Untuk itu dibutuhkan pemahaman terhadap nilai-nilai sosial yang baik dan yang buruk, sehingga kelak anak dapat berkembang menjadi makhluk sosial yang sehat dan bertanggung

${ }^{13}$ Ibid; 22

Vol. 1, Nomor 1, Maret 2019 
jawab. ${ }^{14}$

Setelah proses perkembangan sosial di atas maka perlu kita paparkan ciri-ciri perkembangan sosial anak usia dini, sehingga pada masa peka dalam perkembangan sosial anak usia dini yang dapat dicirikan melalui berbagai kegiatan yang ditunjukkan oleh seorang anak terhadap anak lainnya, sebagai berikut:

1. Adanya minat untuk melihat anak yang lain dan berusaha mengadakan kontak sosial dengan mereka.

2. Mulai bermain dengan mereka

3. Mencoba untuk bergabung dan bekerjasama dalam bermain.

4. Lebih menyukai bekerja dengan 2 atau 3 anak yang dipilihnya sendiri.

Berikut secara lebih spesifik akan diberikan contoh tentang ciri umum perkembangan sosial anak usia 4-5 tahun:

a. Ciri Umum perkembangan sosial anak usia 4-5 tahun:

1). Mulai bermain dan berkomunikasi dengan anak-anak lain.

2). Berani dan mempunyai rasa ingin tahu yang besar.

3). Menunjukkan perhatian untuk mengetahui lebih jauh tentang perbedaan jenis kelamin.

b. Ciri umum perkembangan sosial anak usia 5-6 tahun:

1). Dapat bergaul dengan semua teman.

2). Merasa puas dengan prestasi yang dicapai

3). Tenggang rasa terhadap keadaan orang lain.

4). Dapat mengendalikan emosi. ${ }^{15}$

Anak Usia Dini biasanya mudah bersosialisasi dengan orang sekitarnya, umumnya anak memiliki satu atau dua sahabat, tetapi sahabat ini mudah berganti, mereka pada umumnya mudah dan cepat menyesuaikan diri secara sosial, sahabat yang dipilih biasanya yang memiliki jenis kelamin yang sama, kemudian berkembang kepada jenis kelamin yang berbeda-beda. Kelompok bermain anak usia dini ini cenderung kecil dan tidak terorganisasi secara baik, oleh karena itu kelompok ini cepat berganti. Patten (1932) mengamati tingkah laku sosial Anak Usia

\footnotetext{
${ }^{14}$ Bambang Sujiono \& Yuliani Nurani Sujono, Mencerdaskan Perilaku Anak Usia Dini ; (PT. Alex Media Komputindo Kelompok Gramedia; Jakarta), hal. 77.

${ }^{15} \mathrm{Ibid} ; 79$
}

Jurnal Pelang̉i Jurnal pemikiran dan penelitian pendidkan Islam anak Usia Dini 
Dini ketika mereka sedang bermain bebas sebagai berikut:

a. Tingkah laku Unoccupied. Anak tidak bermain dengan sesungguhnya. Ia mungkin berdiri disekitar anak lain dan memandang temannya tanpa melakukan kegiatan apapun.

b. Bermain soliter. Anak bermain sendiri dengan menggunakan alat permainan berbeda dengan apa yang dimainkan oleh teman yang ada didekatnya, mereka tidak berusaha untuk saling berbicara.

c. Tingkah laku onlooker. Anak menghabiskan waktu dengan mengamati, kadang memberi komentar tentang apa yang dimainkan anak lain, tetapi tidak berusaha bermain bersama.

d. Bermain paralel. Anak bermain dengan saling berdekatan, tetapi tidak sepenuhnya bermain bersama dengan anak yang lain, mereka menggunakan mainan yang sama, berdekatan tetapi dengan cara yang tidak saling bergantung.

e. Bermain assosiatif, Anak bermain dengan anak lain tanpa organisasi, tidak ada perang tertentu, masing-masing anak bermain dengan caranya sendiri-sendiri.

f. Bermain kooperatif, anak bermain dalam kelompok dimana ada organisasi, ada pimpinannya, masing-masing anak melakukan kegiatan bermain dalam kegiatan bersama misalnya perang-perangan, sekolah-sekolahan dan lain-lain. ${ }^{16}$

Setelah kita paparkan proses dan ciri-ciri perkembangan sosial anak berikut ini adalah tahap perkembangan sosial anak dimulai sejak ia dilahirkan atau dengan perkataan lain sejak terjadi interaksi antara anak sebagai individu dengan orang-orang yang ada disekitarnya sebagaimana yang di paparkan oleh Lee Catherine yang dikutip oleh Bambang sujiono \& Yuliani Nuraini Sujiono dalam bukunya "Mencerdaskan Perilaku Anak Usia Dini", bahwa perilaku sosial anak berdasarkan tahapan usia perkembangan adalah sebagai berikut:

1. Pasca Lahir

Anak lebih suka ditinggalkan tanpa diganggu. Merasa senang waktu berkontak erat dengan tubuh ibu. Menangis keras apabila merasa tidak enak, tetapi bila didekap erat atau diayun dengan lembut anak

${ }^{16}$ Slamet Suryanto, Dasar-dasar pendidikan anak usia dini, (Yogyakarta: Hikayat, 2005), hal. 6, yang dikutip dari: Patten, 1932 
akan berhenti menangis.

2. Satu bulan sampai tiga bulan

Merasa kehadiran ibu dan memandang ke arahnya bila ibu mendekati. Terus menerus mengamati setiap gerakan orang yang berada di dekatnya. Berhenti menangis bila diajak bermain atau bicara oleh siapa saja yang bersikap ramah.

3. Enam bulan

Penuh minat terhadap segala sesuatu yang sedang terjadi disekitarnya. Jika akan diangkat anak akan mengulurkan kedua tangannya. Tertawa kecil bila diajak bermain, walaupun biasanya bersahabat tetapi tidak langsung menyambut dan memberi respon terhadap orang yang tidak dikenalnya.

4. Sembilan bulan sampai dua belas bulan

Mengerti kata tidak, melambaikan tangan, bertepuk tangan atau menggoyangkan tangan mengikuti nyanyian. Bermain dengan orang dewasa yang dikenal dan memperhatikan serta meniru tindakan orang dewasa. Mulai memahami dan mamatuhi perintah yang sederhana.

5. Delapan belas bulan sampai dua puluh satu bulan

Ketergantungan terhadap orang lain dalam hal bantuan, perhatian dan kasih sayang. Mengerti sebagian apa yang dikatakan kepada dirinya dan mengulangi kata yang diucapkan orang dewasa.

6. Dua tahun sampai dua setengah tahun

Mempunyai minat yang besar dalam hal mengumpulkan kata-kata. Mulai banyak bertanya dan bisa menunjukkan ciri dan sebagian anggota tubuh apabila ditanya. Senang mendapat persetujuan orang dewasa dan banyak bercakap-cakap.

7. Tiga tahun sampai lima tahun

Berbicara bebas pada dirinya sendiri, orang lain bahkan mainannya, berbicara dengan lancar, bermain dengan kelompok. Anak kadang merasa puas bila bermain sendiri untuk waktu yang lama dan mulai menyenangi kisah seseorang/tokoh dalam film.

8. Pola Perilaku Sosial

Pola perilaku sosial pada anak usia dini dapat dibedakan menjadi dua perilaku, yaitu pola perilaku sosial yang sesuai dengan harapan

Jurnal Pelang̉i Jurnal pemikiran dan penelitian pendidkan Islam anak Usia Dini 
kelompok dan pola perilaku tidak sosial yang tidak sesuai dengan harapan kelompok.

1. Pola Perilaku Sosial

a). Meniru

Agar sama dengan kelompok, anak meniru sikap dan perilaku orang yang sangat ia kagumi.

b). Persaingan

Keinginan untuk mengungguli dan mengalahkan orangorang lain sudah tampak pada usia empat tahun. Ini dimulai di rumah dan kemudian berkembang dalam bermain dengan anak di luar rumah.

c). Kerja sama

Pada akhir tahun ketiga bermain kooperatif dan kegiatan kelompok mulai berkembang dan meningkat baik dalam frekuensi maupun lamanya berlangsung, bersamaan dengan meningkatnya kesempatan untuk bermain dengan anak lain.

d). Simpati

Karena simpati membutuhkan pengertian tentang perasaanperasaan dan emosi orang lain maka hal ini hanya kadangkadang timbul sebelum tiga tahun. Semakin banyak kontak bermain, semakin cepat simpati akan berkembang.

e). Empati

Seperti halnya simpati, empati membutuhkan pengertian tentang perasaan dan emosi orang-orang lain tetapi di samping itu juga membutuhkan kemampuan untuk membayangkan diri sendiri di tempat orang lain. Relatif hanya sedikit anak yang dapat melakukan hal ini sampai awal masa kanak-kanak berakhir. Biarkan saja anak menuangkan emosinya, setelah itu ajak ia duduk dan beri pemahaman tentang emosinya. Misalnya: bunda sangat sedih adik membuang susu. Bunda beli susu itu dengan bekerja. Dengan demikian, si anak anak mengenali emosi orang tuanya. Sebaiknya, sedini mungkin orang tua memberikan simulasi atau rangsangan yang sesuai, agar anak dapat mempelajari keterampilan-keterampilan emosi yang harus dimilikinya. Tentunya orang tua harus mengenali 
diri sendiri sebelum mengajari anak mengenal emosinya.

\section{Bermain Peran (Role Palying)}

Pengertian bermain peran adalah salah satu bentuk pembelajaran, dimana peserta didik ikut terlibat aktif memainkan peran-peran tertentu. Bermain pada anak merupakan salah satu sarana untuk belajar. Melalui kegiatan bermain yang menyenangkan, anak berusaha untuk menyelidiki dan mendapatkan pengalaman yang kaya, baik pengalaman dengan dirinya sendiri, orang lain maupun dengan lingkungan di sekitarnya.

Terdapat lima karakteristik bermain peran (Role Playing), yaitu:

1. Merupakan sesuatu yang menyenangkan dan memiliki nilai yang positif bagi anak.

2. Didasari motivasi yang muncul dari dalam. Jadi anak melakukan kegiatan itu atas kemauannya sendiri.

3. Sifatnya spontan dan sukarela, bukan merupakan kewajiban. Anak merasa bebas memilih apa saja yang ingin dijadikan alternatif bagi kegiatan bermainnya.

4. Senantiasa melibatkan peran aktif dari anak, baik secara fisik maupun mental.

5. Memiliki hubungan sistematik yang khusus dengan sesuatu yang bukan bermain, seperti kemampuan kreatif, memecahkan masalah, kemampian berbahasa, kemampuan memperoleh teman sebanyak mungkin dan sebagainya.

Bermain merupakan bagian terbesar dalam kehidupan anak-anak untuk dapat belajar mengenal dan mengembangkan keterampilan sosial dan fisik, mengatasi situasi dalam kondisi sedang terjadi konflik. Secara umum bermain sering dikaitkan dengan kegiatan anak-anak yang dilakukan secara spontan dan dalam suasana riang gembira. Dengan bermain berkelompok anak akan mempunyai penilaian terhadap dirinya tentang kelebihan yang dimilikinya sehingga dapat membantu pembentukkan konsep diri yang positif, pengelolaan emosi yang baik, memiliki rasa empati yang tinggi, memiliki kendali diri yang bagus, dan memiliki rasa tanggung jawab yang tinggi.

Bermain peran (role playing) merupakan sebuah permainan di mana para pemain memainkan peran tokoh-tokoh khayalan dan berkolaborasi 
untuk merajut sebuah cerita bersama. Para pemain memilih aksi tokohtokoh mereka berdasarkan karakteristik tokoh tersebut, dan keberhasilan aksi mereka tergantung dari sistem peraturan permainan yang telah ditetapkan dan ditentukan, asalkan tetap mengikuti peraturan yang ditetapkan, para pemain bisa berimprovisasi membentuk arah dan hasil akhir permaian.

Oktaviani menyatakan lima pengertian bermain di antaranya:

1. Sesuatu yang menyenangkan dan memiliki nilai positif bagi anak.

2. Bermain tidak memiliki tujuan ekstrinsik namun motivasinya lebih bersifat intrinsik.

3. Bersifat spontan dan sukarela tidak ada unsur keterpaksaan dan bebas dipilih oleh anak.

4. Melibatkan peran aktif keikutsertaan anak.

5. Memiliki hubungan sistematik yang khusus dengan sesuatu yang bukan bermain, seperti misalnya: kreativitas, pemecahan masalah, belajar bahasa, perkembangan sosial, dan sebagainya. ${ }^{17}$

Santrock menyatakan bermain peran (role play) ialah suatu kegiatan yang menyenangkan. Secara lebih lanjut bermain peran merupakan suatu kegiatan yang dilakukan seseorang untuk memperoleh kesenangan. Role playing merupakan suatu metode bimbingan dan konseling kelompok yang dilakukan secara sadar dan diskusi tentang peran dalam kelompok. $^{18}$

Didalam kelas, suatu masalah diperagakan secara singkat sehingga siswa dapat mengenali karakter tokoh seperti apa yang siswa peragakan tersebut atau yang menjadi lawan mainnya memiliki atau kebagian peran seperti apa. Santrock juga menyatakan bermain peran memungkinkan anak mengatasi frustrasi dan merupakan suatu medium bagi ahli terapi untuk menganalisis konflik-konflik anak dan cara-cara mereka mengatasinya. ${ }^{19}$

Ginnot menyatakan bermain peran diyakini sebagai sarana per-

${ }^{17}$ Dikutip dari: Oktaviani, 2008

${ }^{18}$ Siska, Yulia. Penerapan Metode Bermain Peran (Role Playing) Dalam Meningkatkan Keterampilan Sosial dan Keterampilan Berbicara Anak Usia Dini. Penelitian Tindakan Kelas. Edisi Khusus 2, 2011. Hal.

${ }^{19}$ Joyce, B. R., \& Weil, M. Role Playing; Studying Social Behavior and Values, In Models of Teaching, Allyn and Bacon, (2000). hal, 23. 
kembangan potensi juga dapat dijadikan sebagai media terapi. Terapi bermain peran khususnya merupakan pendekatan yang sesuai untuk melakukan konseling dengan anak karena bermain adalah hal yang alami bagi anak. Melalui manipulasi mainan, anak dapat menunjukkan bagaimana perasaan mengenai dirinya, orang-orang yang penting serta peristiwa dalam hidupnya secara lebih memadai daripada melalui katakata.

Ginnot menegaskan bahwa bermain peran merupakan seperangkat prosedur yang digunakan untuk melakukan konseling dengan anak melalui penggunaan secara sistematis dari metode bermain, permainan, dan alat permainan. Van Fleet menyatakan bermain peran merupakan intervensi yang dikembangkan yang berkaitan dengan penggunaan sistematis dari metode bermain oleh seorang konselor untuk membawa peningkatan dalam kemampuan siswa sampai penampilan yang optimal di sekolah. Bermain peran juga meliputi penggunaan bermain secara sistematis untuk mengatasi kesulitan-kesulitan anak, mengembangkan pola perilaku adaptif, mengendalikan diri siswa yang agresifnya tinggi, meningkatkan kemampuan berempati, dapat mengelola emosi, dapat menjadi individu yang bertanggung jawab, memiliki interpersonal skill yang bagus dan dapat memecahkan masalah secara efektif dan bijaksana. ${ }^{20}$

Corsini menyatakan bahwa bermain peran dapat digunakan sebagai alat untuk mendiagnosis dan mengerti seseorang dengan cara mengamati perilakunya waktu memerankan dengan spontan situasi-situasi atau kejadian yang terjadi dalam kehidupan yang sebenarnya. Selain itu teknik bermain peran dapat digunakan sebagai media pengajaran melalui proses modeling anggota kelompok dapat belajar lebih efektif keterampilan-keterampilan yang berhubungan dengan interpersonal, dengan mengamati berbagai macam cara dalam memecahkan masalah.

Keempat asumsi tersebut sebagai antara lain:

1. Bermain peran dilaksanakan berdasarkan pengalaman siswa dan isi dari pelaksanaan teknik ini yaitu pada situasi "disini pada saat ini".

2. Bermain peran memungkinkan siswa untuk mengungkapkan pe-

${ }^{20}$ Wintari, Ni Luh Mira, dkk,. Penerapan Metode Bermain Peran (Role Playing) Berbantuan Media Konkret Dalam Meningkatkan Perkembangan Sosial emosional Anak. E-Journal PG PAUD Universitas Pendidikan Ganesha., 2015, hal. 12.

Jurnal Pelangi Jurnal pemikiran dan penelitian pendidkan Islam anak Usia Dini 
rasaannya yang tidak dapat dikenal tanpa bercermin pada orang lain. Mengungkapkan perasaannya untuk mengurangi beban emosional.

3. Teknik bermain peran ini berasumsi bahwa emosi dan ide-ide dapat diangkat ke taraf sadar untuk kemudian ditingkatkan melalui proses kelompok. Pemecahan tidak selalu datang dari orang tertentu, tetapi bisa saja muncul dari reaksi pengamat terhadap masalah yang sedang diperankan. Dengan demikian, para siswa dapat belajar dari pengalaman orang lain tentang cara memecahkan masalah yang pada gilirannya dapat dimanfaatkan untuk mengembangkan dirinya secara optimal. Dengan demikian, siswa belajar dari pengalaman orang lain tentang cara memecahkan masalah yang pada gilirannya dapat dimanfaatkan untuk mengembangkan dirinya secara lebih optimal lagi.

4. Teknik bermain peran berasumsi bahwa proses psikologis yang tersembunyi, berupa sikap, nilai dan sistem keyakinan, dapat diangkat ke taraf sadar melalui kombinasi pemeranan secara spontan. Dengan demikian, siswa dapat menguji sikap dan nilainya yang sesuai dengan orang lain, apakah sikap dan nilai yang dimilikinya perlu dipertahankan atau diubah. Tanpa bantuan orang lain, para peserta didik sulit untuk menilai sikap dan nilai yang dimilikinya.

\section{4. $\quad$ Metode Role Playing (Bermain Peran)}

Metode bermain peran merupakan suatu cara yang digunakan untuk meniru cara bertingkah laku seseorang dalam sebuah drama. Tingkah laku yang ditekankan dalam metode bermain peran, kaitannya dengan hubungan sosial. Santoso menyatakan bahwa metode bermain peran mendayagunakan pengaruh kinestetik atau gerakan, sebab subjek diminta untuk melakukan suatu peranan tertentu. Metode ini digunakan untuk mengembangkan kemampuan interpersonal atau kemampuan individu untuk melakukan interaksi dengan orang lain. ${ }^{21}$

\section{KESIMPULAN}

Pengembangan sosial-emosional anak melalui metode Role Palying

${ }^{21}$ Ibid, hal 12, Dikutip dari: Santoso, 2010 
(Bermain Peran) di kelompok B Anak Usia Dini adalah perkembangan sosial dan emosi merupakan suatu proses pemerolehan kemampuan untuk berperilaku yang sesuai dengan keinginan yang berasal dari dalam diri seseorang anak yang sedang membutuhkan upaya-upaya pendidikan untuk mencapai optimalisasi semua aspek perkembangan baik perkembangaan fisik maupun psikis, yaitu intelektual, bahasa, motorik, dan sosio emosional, lewat kegiatan yang menyenangkan dan sesuai dengan tuntutan dan harapan-harapan sosial yang berlaku di masyarakat

\section{REFERENSI}

Bambang Sujiono \& Sujono Nurani Yuliani, Mencerdaskan Perilaku Anak Usia Dini, Jakarta: PT. Alex Media Komputindo Kelompok Gramedia, 2012.

Dwi Novita Sari. Penerapan Model Pembelajaran Role Playing Untuk Meningkatkan

Motivasi dan Hasil Belajar Siswa Pada Mata Pelajaran PKn Kelas IV SD Negeri 2 Kesumadadi, Jurusan Ilmu Pendidikan, Fakultas Keguruan dan Ilmu Pendidikan Universitas Lampung, 2016, hal 17, Dikutip Dari: Hanafiah, 2009: 41

, Dikutip dari: Sudjana, 2009: 89

Deska Santi Julyasari. Penerapan metode Bermain Peran Dalam Mengembangkan Kreativitas Anak Usia Dini Di Taman Kanak-Kanak Dzakiyah Kedamaian Antasari Bandar lampung. Fakultas Tarbiyah dan Keguruan, Universitas Islam Negeri Raden Intan, Lampung, 2017, hal. iii

Hasan Ihlas, Pendidikan Anak Usia Dini, (Konsep,filosofi, dan paradigma baru, Edukasi Mitra Grafika, Palu, 2017.

Joyce, B. R., \& Weil, M. Role Playing; Studying Social Behavior and Values, In Models of Teaching, Allyn and Bacon, 2000.

Nugraha Ali, Yeni Rahmawati; Metode Pengembangan Sosial Emosional, Universitas Terbuka, Jakarta, 2009.

Slamet Suryanto, Dasar-dasar pendidikan anak usia dini, Yogyakarta: Hikayat, 2005.

Soetjiningsih Hari Christiana, perkembangan Anak sejak pembuahan sampai dengan Kanak-kanak akhir, Prenda, Jakarta, 2014.

Jurnal Pelangi Jurnal pemikiran dan penelitian pendidkan Islam anak Usia Dini 
W.J.S. Purwadarminta, Kamus Besar Bahasa Indonesia, (Jakarta: Balai Pustaka, 2005.

Wintari, Ni Luh Mira, dkk,. Penerapan Metode Bermain Peran (Role Playing) Berbantuan Media Konkret Dalam Meningkatkan Perkembangan Sosial emosional Anak. E-Journal PG PAUD Universitas Pendidikan Ganesha., 2015.

Yulia Siska, Penerapan Metode Bermain Peran (Role Playing) Dalam Meningkatkan Keterampilan Sosial dan Keterampilan Berbicara Anak Usia Dini. Penelitian Tindakan Kelas. Edisi Khusus 2, 2011.

Z Rofiah Opik, Metode Pengembangan Kognitif, Jakarta: UT; 2005. 